\title{
Metaphylactic effect of calcium on milk composition and animal health in post-partum dairy cows
}

\author{
KÁSSIO D. ALBANI ${ }^{1}$, LEANDRO S. LOPES ${ }^{1,2,}$ GABRIELA CAMPIGOTTO $^{1}$, \\ MATHEUS D. BALDISSERA ${ }^{3}$ and ALEKSANDRO S. DA SILVA ${ }^{1,4}$
}

\author{
'Programa de Pós-Graduação em Zootecnia, Universidade do Estado de Santa Catarina/UDESC, \\ Rua Beloni Trombeta Zanim, 680, Santo Antônio, 89815-630 Chapecó, SC, Brazil \\ ${ }^{2}$ Departamento de Zootecnia, Universidade Federal de Minas Gerais, Avenida Presidente \\ Antônio Carlos, 6627, Pampulha, 31270-901 Belo Horizonte, MG, Brazil \\ ${ }^{3}$ Programa de Pós-Graduação em Farmacologia, Universidade Federal de Santa Maria, \\ Avenida Roraima, 1000, 97105-900 Santa Maria, RS, Brazil \\ ${ }^{4}$ Departamento de Zootecnia, Universidade do Estado de Santa Catarina/UDESC, Rua \\ Beloni Trombeta Zanin, 680, Santo Antônio, 89815-630 Chapecó, SC, Brazil
}

Manuscript received on June 11, 2018; accepted for publication on September 3, 2018

\begin{abstract}
How to cite: ALBANI KD, LOPES LS, CAMPIGOTTO G, BALDISSERA MD AND SILVAAS. 2019. Metaphylactic effect of calcium on milk composition and animal health in post-partum dairy cows. An Acad Bras Cienc 91: e20180589. DOI 10.1590/0001-3765201920180589.
\end{abstract}

\begin{abstract}
The aim of this study was to evaluate the effects of subcutaneous calcium administration in postpartum dairy cows with respect to carbohydrate, protein and lipids metabolism, as well as its effects on milk composition. Twenty post-partum dairy cows were randomly divided into two groups $(\mathrm{n}=10)$ : a control and a treated group with a single dose $(150 \mathrm{~mL})$ of calcium. Blood collection was performed on post-partum days 1, 2, 3, 7 and 10. In addition, we measured serum levels of total calcium, total proteins, albumin, globulins, glucose, cholesterol, triglycerides, as well as creatine kinase (CK) activity. We determined milk composition on post-partum days 5,10 and 20. Serum total calcium levels was higher on post-partum days 3 and 7 in the treated group. Serum urea (day 3) and triglycerides (days 7 and 10) levels were higher in the treated group, as were CK activity levels at post-partum days 2 and 3. Serum glucose and cholesterol levels were lower on post-partum day 2 in treated animals. Fat (day 20) and lactose (day 10) content in milk samples were higher than in the treated animals. We concluded that treatment with calcium in cows during the post-partum period changes biochemical variables related to metabolism.
\end{abstract}

Key words: animal health, dairy cattle, pre-delivery, subcutaneous calcium, hypocalcemia.

\section{INTRODUCTION}

Livestock production, including milk production,

Correspondence to: Leandro Sâmia Lopes

E-mail: leandrosamia@uol.com.br

ORCid: https://orcid.org/0000-0002-0641-6598

Aleksandro Schafer da Silva

E-mail: dasilva.aleksandro@gmail.com

ORCid: https://orcid.org/0000-0002-9860-1933 is one of the largest agribusiness sub-sectors, with a global asset value of at least $\$ 1.4 \mathrm{~T}$ (Thornton 2010). Some phases of production are critical to animal health, including the peripartum period, defined as the period 21 days before parturition and 21 days after parturition. During this period, several metabolic and endocrine alterations provoke metabolic disturbances in the post-partum animal; 
it is a period when the animal has a negative energy balance, using a large portion of her reserves for production of colostrum and milk (HernándezCastellano et al. 2017).

Hypocalcemia, associated with placental retention, is the principal disturbance found in cows during the post-partum period, since the animals do not maintain physiological concentrations of serum calcium (Goff and Koszewski 2018). According to McLaren et al. (2006), approximately $5 \%$ of cases are diagnosed as clinical hypocalcemia, while subclinical hypocalcemia occurs principally in multiparous cows, affecting up to $54 \%$ of the herd (Reinhardt et al. 2011). This condition results from excessive animal effort during parturition, as well as from the large demand of calcium in the generation of colostrum (McGrath et al. 2016).

Hypocalcemia can contribute to dystocia, uterine prolapse, retention of fetal membranes, endometritis, reduction of fertility, mastitis and reduction of ruminal motility, frequently requiring pharmacological interventions (Curtis et al. 1983, Borsberry and Dobson 1989). According to Santos (2011), these disturbances can be prevented by two main methods, i.e., the use of $\mathrm{Ca}$ deficient diets, which stimulate activity and paratormonium secretion (PTH) (negative feedback) (Albani and Da Silva 2017); or one second method, easier to implement and more effective in the control of subclinical hypocalcemia, is the manipulation of the cationic-anionic balance of the diet, which influences PTH activity and, therefore, the mechanism of active absorption of calcium (Albani et al. 2017). Another option would be oral calcium supplementation, which was beneficial even for dairies with a very low incidence of hypocalcemia (Oetzel and Miller 2012, Oetzel 2013), however, there is controversy as to the beneficial effects of this practice (Martinez et al. 2016).

According to literature, the subclinical hypocalcemia compromised appetite, altered metabolism, and impaired function of immune cells in dairy cows (Martinez et al. 2012, 2014). The same research group had already verified that the relative risk of developing metritis decreased by $22 \%$ for every $1 \mathrm{mg} / \mathrm{dL}$ increase in serum calcium (Martinez et al. 2014), which shows the importance of maintaining in levels of this adequate mineral. Calcium application in the post-partum period as a preventive measure is a common practice on many farms, but the effects of its application on metabolism of carbohydrates, lipids and proteins needs more studies. Thus, the aim of this study was to evaluate whether administration of subcutaneous calcium soon after parturition had positive effects on animal's health, as well as on maintenance of physiological serum calcium levels, consequently avoid hypocalcemia, characterized in cows when calcium levels are lower $8.0 \mathrm{mg} / \mathrm{dL}$ (Blanc et al. 2014).

\section{MATERIALS AND METHODS}

The experiment was approved by the Ethics Committee on Animal Research of the Universidade do Estado de Santa Catarina (UDESC), under protocol number 3317190417.

The present study was conducted on a farm in Pinhalzinho (Santa Catarina, Brazil), where milk production is the principal activity. The farm includes approximately 50 lactating animals. There is a pasture production system, a prepartum confinement sob compost barn system, with animals individually fed and maintained in yokes. The prepartum cows were separated 21 days before parturition and received a diet (pre-dried, silage and concentrate) (Table I) provided twice a day. After parturition, the animals received a postpartum diet (Table I) twice a day individually, and they were observed daily. Importantly, on the farm, all ingredients were added in a device known as a "wagon mixer", and after homogenization, feed was offered to the individual animals. Per cow, the total food supply was $20 \mathrm{~kg}$ and $30 \mathrm{~kg} /$ day, with 
pre-dried oats at $9 \mathrm{~kg}$ and $7 \mathrm{~kg} /$ day, in the pre- and post-partum periods, respectively.

Twenty multiparous Holstein cows (two to four lactations) and milk production $(28 \pm 4$ L) were divided into two groups of ten animals each: the control group (CG) and animals that received treatment with injectable calcium to aid in the prevention of subclinical hypocalcemia. The treated animals received a single dose of 150 $\mathrm{mL}$ of calcium subcutaneously after parturition (2 hours). The drug used was composed of calcium gluconate monohydrate $(22.83 \mathrm{~g})$, D-calcium saccharide tetrahydrate $(0.0387)$ and calcium lactate pentahydrate $(3.03 \mathrm{~g})$ for each $100 \mathrm{~mL}$ of product.

During the experiment, homogenized food samples (silage, pre-dried and concentrate) were collected, packed and sent to the laboratory for analysis (Table I). Blood samples were collected from the caudal vein using tubes without anticoagulant on days 1 (parturition), and post-partum days 2, 3, 7 and 10. Samples were transported to laboratory and centrifuged (3500 $\mathrm{rpm}, 10 \mathrm{~min}$ ) to obtain serum. The serum was collected and stored at $-20{ }^{\circ} \mathrm{C}$ until assay. Milk samples were collected on post-partum days 5, 10 and 20 for analysis of milk composition (fat, protein, lactose and total solids) using automatic equipment (LactoStar Funke Gerber $\left.{ }^{\circledR}\right)$.

Serum levels of total calcium, total protein, albumin, cholesterol, triglycerides, glucose and urea, as well as creatine kinase (CK) activity, were measured using commercial kits (Analisa ${ }^{\circledR}$ ) using a semi-automated analyzer (Bio Plus $2000^{\circledR}$ ) according to manufacturers' instructions. The serum globulin levels were obtained by subtracting albumin from total protein levels.

On the day of blood collection, a drop of blood collected form caudal vein was used to quantify ketone bodies levels using a portable digital meter

TABLE I

Ingredients and chemical composition of diet provided to the cows in the pre and post-partum.

\begin{tabular}{|c|c|c|}
\hline INGREDIENTS * & $\begin{array}{c}\text { Prepartum diet } \\
(\%)\end{array}$ & $\begin{array}{c}\text { Post-partum diet } \\
(\%)\end{array}$ \\
\hline Corn silage & 60.6 & 69.3 \\
\hline Pre-Dried Oats & 27.3 & 16.2 \\
\hline Commercial Concentrate & 12.1 & 13.9 \\
\hline Commercial Mineral & - & 0.6 \\
\hline \multicolumn{3}{|c|}{$\begin{array}{l}\text { CHEMICAL COMPOSITION (\% DR) AT TOTAL } \\
\text { DIET }\end{array}$} \\
\hline Crude protein & 14.2 & 12.0 \\
\hline Neutral detergent fiber (NDF) & 21.4 & 39.0 \\
\hline Acid detergent fiber (ADF) & 14.1 & 21.8 \\
\hline Calcium & 0.81 & 0.73 \\
\hline Phosphor & 0.40 & 0.38 \\
\hline Magnesium & 0.25 & 0.19 \\
\hline Sodium & 0.16 & 0.13 \\
\hline Potassium & 1.16 & 1.21 \\
\hline Chlorine & 0.63 & 0.17 \\
\hline Sulfur & 0.54 & 0.14 \\
\hline DCAD & -120.60 & 231.39 \\
\hline
\end{tabular}

Note: $(\mathrm{Na}+\mathrm{K})-(\mathrm{Cl}+\mathrm{S})$ in $\mathrm{mEq} / \mathrm{kg}$ of dry matter. * All ingredients are mixed, and offered to animals within 30 min after homogenization. 
(KetoVet TD-4235 ${ }^{\circledR}$ ) following the manufacturer's recommendations.

The data were subjected to normality testing (Shapiro-Wilk), and the data that did not present normality were transformed to logarithms for normalization. Subsequently, the data were compared using the Student's t test, with $P<0.05$ between groups (control and treated) and over time (repeated measures) considered statistically significant.

\section{RESULTS}

After parturition, no clinical signs linked to hypocalcemia, placenta retention and mastitis were observed in either group. Serum total calcium levels were higher in treated animals than in the control group on post-partum days 3 and 10 (Figure 1). Over time, a calcium increase from day 2 to 3 ( $P$ $<0.05$ ) was observed.

Serum levels of urea (post-partum day 3) and triglycerides (post-partum days 7 and 10), and CK activity (days 2 and 3 post-partum) were higher in the treated group than in the control group. Serum levels of glucose and cholesterol were lower in the treated group than in the control group on post- partum day 2 (Tables II and III). No difference was observed between groups regarding ketone bodies, total proteins, albumin or globulin content (Tables II and III).

Over time, ketone body levels increased after delivery in both groups (Table II), and globulin levels were higher on post-partum day 3 than on other evaluated days (control group only) (Table II). CK activity increased soon after delivery in both groups, and decreased on day 10 (Table III). Glucose and triglyceride serum levels were higher shortly after calving, and then decreased in both groups (Table III). Cholesterol levels only differed over time in the control group, that is, on postpartum days 2, 3 and 7 compared to the others days (Table III). Other variables (total protein, urea and albumin) did not differ over time $(P<0.05)$.

Regarding milk composition, we observed no difference between groups in terms of proteins or defatted dry extract. However, fat and lactose content were higher in the treated group than the control group on days 20 and 10 post-partum, respectively (Table IV). Over time, there were no differences in milk composition variables $(P>0.05$ - Table IV).

- Control $\square$ Treated

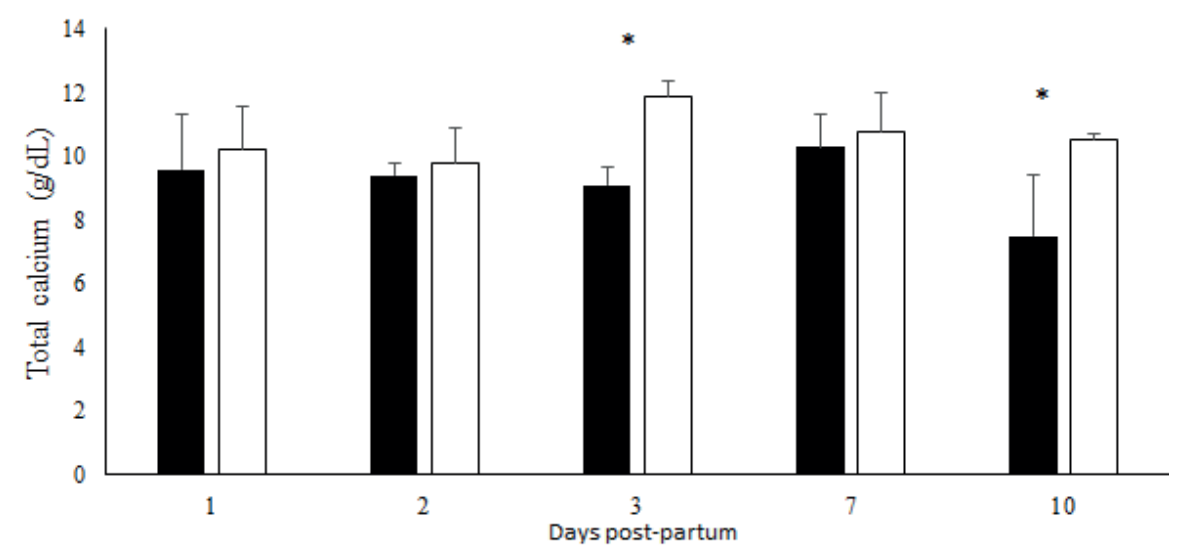

Figure 1 - Serum total calcium levels of cows supplemented with calcium on days 1, 2, 3, 7 and 10 post-partum. Over time, a calcium increase from day 2 to $3(P<0.05)$ was observed. Note: The asterisk $(*)$ illustrates the significant difference between groups at each time point of the experiment $(P<0.05)$. 
TABLE II

Serum levels of ketone bodies, total proteins, albumin, globulin and urea on post-partum of cows supplemented with calcium on the day of parturition.

\begin{tabular}{|c|c|c|c|c|}
\hline Variable & Day & Control & Supplemented & $P$ value \\
\hline & 1 & $0.76 \pm 0.24^{\mathrm{C}}$ & $0.54 \pm 0.1^{\mathrm{C}}$ & 0.341 \\
\hline & 2 & $0.84 \pm 0.13^{\mathrm{C}}$ & $0.69 \pm 0.13^{\mathrm{C}}$ & 0.083 \\
\hline \multirow[t]{3}{*}{ Ketone bodies $(\mathrm{mMol} / \mathrm{L})$} & 3 & $0.91 \pm 0.20^{\mathrm{BC}}$ & $0.82 \pm 0.21^{\mathrm{BC}}$ & 0.434 \\
\hline & 7 & $1.5 \pm 0.85^{\mathrm{AB}}$ & $1.42 \pm 0.40^{\mathrm{A}}$ & 0.744 \\
\hline & 10 & $1.55 \pm 0.54^{\mathrm{A}}$ & $1.27 \pm 0.51^{\mathrm{AB}}$ & 0.131 \\
\hline \multirow[t]{3}{*}{$P$ value } & & 0.001 & 0.001 & \\
\hline & 1 & $7.3 \pm 1.07$ & $8.02 \pm 0.85$ & 0.673 \\
\hline & 2 & $9.85 \pm 2.11$ & $8.71 \pm 2.10$ & 0.431 \\
\hline \multirow[t]{3}{*}{ Total proteins (g/dL) } & 3 & $11.5 \pm 2.9$ & $10.0 \pm 2.4$ & 0.709 \\
\hline & 7 & $7.91 \pm 1.08$ & $7.51 \pm 1.53$ & 0.849 \\
\hline & 10 & $7.77 \pm 1.15$ & $7.77 \pm 1.21$ & 0.978 \\
\hline \multirow[t]{3}{*}{$P$ value } & & 0.092 & 0.145 & \\
\hline & 1 & $2.86 \pm 0.56$ & $3.38 \pm 0.85$ & 0.455 \\
\hline & 2 & $4.53 \pm 1.05$ & $4.11 \pm 1.08$ & 0.675 \\
\hline \multirow[t]{3}{*}{ Albumin $(g / d L)$} & 3 & $3.50 \pm 0.68$ & $4.11 \pm 0.93$ & 0.753 \\
\hline & 7 & $3.27 \pm 0.79$ & $3.46 \pm 0.81$ & 0.871 \\
\hline & 10 & $3.01 \pm 0.26$ & $2.96 \pm 0.39$ & 0.849 \\
\hline \multirow[t]{3}{*}{$P$ value } & & 0.061 & 0.356 & \\
\hline & 1 & $4.44 \pm 1.00^{\mathrm{B}}$ & $4.64 \pm 1.06$ & 0.905 \\
\hline & 2 & $5.32 \pm 2.20^{\mathrm{AB}}$ & $5.03 \pm 1.19$ & 0.844 \\
\hline \multirow[t]{3}{*}{ Globulin (g/dL) } & 3 & $8.00 \pm 2.65^{\mathrm{A}}$ & $6.05 \pm 1.94$ & 0.074 \\
\hline & 7 & $4.55 \pm 1.20^{\mathrm{B}}$ & $4.05 \pm 1.35$ & 0.678 \\
\hline & 10 & $4.76 \pm 1.25^{\mathrm{B}}$ & $4.81 \pm 1.07$ & 0.889 \\
\hline \multirow[t]{3}{*}{$P$ value } & & 0.001 & 0.087 & \\
\hline & 1 & $43 \pm 9.6$ & $38.7 \pm 8.48$ & 0.686 \\
\hline & 2 & $34.3 \pm 8.9$ & $44.2 \pm 7.02$ & 0.065 \\
\hline \multirow[t]{3}{*}{ Urea $(\mathrm{mg} / \mathrm{dL})$} & 3 & $35.8 \pm 5.2$ & $47 \pm 8.6$ & $0.040^{*}$ \\
\hline & 7 & $38.0 \pm 7.8$ & $39.3 \pm 11.2$ & 0.845 \\
\hline & 10 & $42.4 \pm 5.0$ & $39.5 \pm 7.8$ & 0.817 \\
\hline$P$ value & & 0.225 & 0.536 & \\
\hline
\end{tabular}

Note: $P<0.05$ in the same line shows difference between groups. $P<0.05$ in the same column shows difference in each group over time (different letters in the same column shows difference between evaluated periods). 
TABLE III

Serum creatine kinase (CK) activity, and glucose, triglycerides and cholesterol levels on post-partum of cows supplemented with calcium on the day of parturition.

\begin{tabular}{|c|c|c|c|c|}
\hline Variable & Day & Control & Supplemented & $P$ value \\
\hline & 1 & $282.1 \pm 143.5^{\mathrm{B}}$ & $294.1 \pm 100.8^{\mathrm{B}}$ & 0.875 \\
\hline & 2 & $113.0 \pm 50.8^{\mathrm{C}}$ & $250.3 \pm 19.0^{\mathrm{B}}$ & $0.001^{*}$ \\
\hline \multirow[t]{3}{*}{$\mathrm{CK}(\mathrm{mg} / \mathrm{dL})$} & 3 & $169.6 \pm 48.5^{\mathrm{C}}$ & $514 \pm 85.9^{\mathrm{A}}$ & $0.001^{*}$ \\
\hline & 7 & $465.0 \pm 32.3^{\mathrm{A}}$ & $485.5 \pm 68.5^{\mathrm{A}}$ & 0.905 \\
\hline & 10 & $258.6 \pm 11.0^{\mathrm{B}}$ & $275 \pm 125.6^{\mathrm{B}}$ & 0.853 \\
\hline \multirow[t]{3}{*}{$P$ value } & & 0.001 & 0.001 & \\
\hline & 1 & $53.6 \pm 23.6^{\mathrm{B}}$ & $72 \pm 23.5^{\mathrm{A}}$ & 0.148 \\
\hline & 2 & $108.6 \pm 27.2^{\mathrm{A}}$ & $85.5 \pm 15.5^{\mathrm{A}}$ & $0.047^{*}$ \\
\hline \multirow[t]{3}{*}{ Glucose (mg/dL) } & 3 & $107.9 \pm 31.4^{\mathrm{A}}$ & $79.2 \pm 22.7^{\mathrm{A}}$ & 0.096 \\
\hline & 7 & $48.6 \pm 15.6^{\mathrm{B}}$ & $47.2 \pm 9.4^{\mathrm{B}}$ & 0.924 \\
\hline & 10 & $69.2 \pm 27.7^{\mathrm{B}}$ & $49.6 \pm 13.6^{\mathrm{B}}$ & 0.175 \\
\hline \multirow[t]{3}{*}{$P$ value } & & 0.001 & 0.008 & \\
\hline & 1 & $10.5 \pm 6.6^{\mathrm{B}}$ & $8.2 \pm 3.9^{\mathrm{BC}}$ & 0.743 \\
\hline & 2 & $36.2 \pm 11.8^{\mathrm{A}}$ & $33.1 \pm 6.5^{\mathrm{A}}$ & 0.834 \\
\hline \multirow[t]{3}{*}{ Triglycerides (mg/dL) } & 3 & $6.69 \pm 2.9^{\mathrm{B}}$ & $6.66 \pm 2.7^{\mathrm{C}}$ & 0.897 \\
\hline & 7 & $7.28 \pm 1.49^{\mathrm{B}}$ & $13.1 \pm 4.4^{\mathrm{B}}$ & $0.001^{*}$ \\
\hline & 10 & $8.00 \pm 2.8^{\mathrm{B}}$ & $12.0 \pm 4.1^{\mathrm{B}}$ & $0.047^{*}$ \\
\hline \multirow[t]{3}{*}{$P$ value } & & 0.001 & 0.001 & \\
\hline & 1 & $62.5 \pm 13.7^{\mathrm{C}}$ & $63.3 \pm 24.0$ & 0.879 \\
\hline & 2 & $131.9 \pm 35.0^{\mathrm{A}}$ & $85.6 \pm 32.0$ & $0.001^{*}$ \\
\hline \multirow[t]{3}{*}{ Cholesterol (mg/dL) } & 3 & $111.4 \pm 32^{\mathrm{A}}$ & $87.1 \pm 31.0$ & 0.067 \\
\hline & 7 & $99.1 \pm 34.2^{\mathrm{AB}}$ & $64.8 \pm 23.2$ & 0.033 \\
\hline & 10 & $73.5 \pm 13.1^{\mathrm{BC}}$ & $59.12 \pm 16.7$ & 0.082 \\
\hline$P$ value & & 0.001 & 0.201 & \\
\hline
\end{tabular}

Note: $P<0.05$ in the same line shows difference between groups. $P<0.05$ in the same column shows difference in each group over time (different letters in the same column shows difference between evaluated periods).

\section{DISCUSSION}

According to literature, fluctuations in blood $\mathrm{Ca}$ were observed after prophylactic intravenous $\mathrm{Ca}$ supplementation in multiparous Jersey $\times$ Holstein crossbreed cows (Blanc et al. 2014). Similarly, we observed also fluctuations, but with significant higher serum total calcium levels in treated animals than in the control group. Researchers verified that the post-partum oral supplementation with
2 doses of 50 to $60 \mathrm{~g}$ of calcium increased this mineral concentration in serum and reduced the prevalence of subclinical hypocalcemia in Jersey cows; but this authors observed that the initial calcemic status highly influenced treatment effects, with subclinically hypocalcemic cows showing a greater serum calcium concentration increase after supplementation than normocalcemic cows (Valldecabres et al. 2018). Based on these data, 
TABLE IV

Milk composition on days 5, 10 and 20 post-partum of cows that received calcium injectable on parturition day.

\begin{tabular}{|c|c|c|c|c|}
\hline Variable (\%) & Day & Control & Supplemented & $P$ value \\
\hline & 5 & $3.35 \pm 0.9$ & $4.18 \pm 1.20$ & 0.340 \\
\hline \multirow[t]{2}{*}{ Fat } & 10 & $3.15 \pm 1.2$ & $3.61 \pm 1.17$ & 0.635 \\
\hline & 20 & $3.34 \pm 1.38$ & $5.44 \pm 2.12$ & $0.027^{*}$ \\
\hline \multirow[t]{2}{*}{$P$ value } & & 0.356 & 0.095 & \\
\hline & 5 & $3.53 \pm 0.15$ & $3.47 \pm 0.10$ & 0.137 \\
\hline \multirow[t]{2}{*}{ Protein } & 10 & $3.35 \pm 0.14$ & $3.50 \pm 0.12$ & 0.080 \\
\hline & 20 & $3.15 \pm 0.11$ & $3.14 \pm 0.10$ & 0.897 \\
\hline \multirow[t]{2}{*}{$P$ value } & & 0.368 & 0.436 & \\
\hline & 5 & $5.17 \pm 0.22$ & $5.09 \pm 0.16$ & 0.834 \\
\hline \multirow[t]{2}{*}{ Lactose } & 10 & $4.75 \pm 0.20$ & $5.14 \pm 0.17$ & $0.012^{*}$ \\
\hline & 20 & $4.61 \pm 0.17$ & $4.58 \pm 0.68$ & 0.817 \\
\hline \multirow[t]{2}{*}{$P$ value } & & 0.265 & 0.652 & \\
\hline & 5 & $9.54 \pm 0.30$ & $9.53 \pm 0.26$ & 0.967 \\
\hline \multirow[t]{2}{*}{ Defatted dry extract } & 10 & $9.18 \pm 0.33$ & $9.58 \pm 0.36$ & 0.535 \\
\hline & 20 & $8.67 \pm 0.32$ & $8.81 \pm 1.2$ & 0.605 \\
\hline \multirow[t]{2}{*}{$P$ value } & & 0.351 & 0.476 & \\
\hline & 5 & $0.85 \pm 0.09$ & $0.86 \pm 0.12$ & 0.950 \\
\hline \multirow[t]{2}{*}{ Minerals } & 10 & $0.89 \pm 0.11$ & $0.88 \pm 0.12$ & 0.912 \\
\hline & 20 & $0.87 \pm 0.08$ & $0.89 \pm 0.09$ & 0.844 \\
\hline$P$ value & & 0.865 & 0.896 & \\
\hline
\end{tabular}

Note: $P<0.05$ in the same line shows difference between groups. $P<0.05$ in the same column shows difference in each group over time (different letters in the same column shows difference between evaluated periods).

the researchers conclude that the oral calcium supplementation seemed to disrupt Ca homeorhetic mechanisms in normocalcemic cows, and future studies should evaluate the long-term implications on production and reproduction (Valldecabres et al. 2018). A study conducted by Jahani-Moghadam et al. (2018) reported that oral Calcium bolus administration increased concentrations of calcium in serum on Day 2 post-partum in Holstein dairy cows, and increased first service conception rates, in cows fed a diet with a positive DCAD prior to calving compared to cows that received no oral $\mathrm{Ca}$ bolus supplementation. It is important emphasize that use of a single dose of calcium $24 \mathrm{~h}$ following parturition was reduced several risks, including retention placenta risk, mastitis, heart disease risk and displaced abomasum in multiparous cows (Leno et al. 2018). Thus, treatment with oral calcium can be considered an approach to prevent not only hypocalcemia but also other disorders of dairy cows during the post-partum period.

After parturition, a negative energy balance favors the occurrence of subclinical or clinical ketosis, as observed by Ceciliani et al. (2018) in dairy cows during the transition period. Although no clinical signs associated with ketosis were observed in this study, it is important to highlight a tendency $(P=0.08)$ toward increased ketone bodies in the control group, with a trend toward fewer ketone bodies in the treated group than in the control 
group. Valldecabres et al. (2018) reported that oral calcium supplementation reduced the incidence of subclinical ketosis in multiparous cows during the post-partum period. The transitory increase in serum urea levels in the treated group can be considered a direct consequence of increased serum total calcium levels, since calcium is principally metabolized via the kidney (Massey and Whiting 1993). In addition, it is important emphasize that increased serum urea levels can indicate substantial catabolism of amino acids, because urea is a major nitrogenous end-product of protein and amino acid catabolism (Gowda et al. 2010).

In cow calving and post-partum, there is an increase in the inflammatory response (LeBlanc 2012), as it is known that inflammatory activity is one factor associated with reduced CK (Lee et al. 2000), and the study indicates that inflammation may initiate a process leading to reduction in CK levels, i.e. the CK may have an anti-inflammatory effect (Bekkelund and Johnsen 2018). However, in our study have increase in serum CK activity observed in calcium-treated animals can be considered an attempt on the part of the organism to provide energy in a period of negative energy balance, such as the post-partum period. This occurs because CK catalyzes the reversible conversion of creatine and ATP to phosphocreatine and ADP (Wallimann et al. 1992), and phosphocreatine serves as an energy reservoir that rapidly produces ATP. Thus, CK is a crucial enzyme for generation of phosphocreatine, functioning as an energy buffer and as an energy carrier (Schlattner et al. 2006). However, it is important emphasize that the augmentation of CK activity can be considered an adverse effect of calcium supplementation, since $\mathrm{CK}$ is released into the circulation from damaged cells (e.g., damaged muscles) (Kim et al. 2016). This can be corroborated by the positive correlation between calcium and CK serum levels during myocardial infarction (Speich et al. 1988). In the present study, we observed that animals treated with calcium had lower serum glucose levels on the second day post-partum than did the control group, demonstrating that calcium can influence carbohydrate metabolism. Glucose reduction may be explained by the fact that glucose is a substrate for lactose synthesis; this phenomenon was observed in cows receiving calcium that produced a higher percentage of lactose in their milk. In agreement with our observations, Valldecabres et al. (2018) demonstrated that Jersey cows prophylactically treated with oral calcium in the post-partum period had lower serum glucose levels than did the control group, while no difference was observed in this parameter in Holstein dairy cows treated orally with calcium boluses (Jahani-Moghadam et al. 2018). Finally, we observed that calcium also altered lipid metabolism, demonstrated by increased triglycerides and decreased cholesterol levels, change that we do not find an explanation in the literature.

We observed that fat and lactose content was higher in animals treated with calcium than in the control group, contrary to observations by Jahani-Moghadam et al. (2018), who no observed difference in milk composition in Holstein dairy cows treated with oral calcium, and contrary as well to observations by Amanlou et al. (2016) in Holstein cows treated subcutaneously with calcium. More recently, Domino et al. (2017) demonstrated that two sources of calcium (calcium gluconate or calcium bolus) did not affect the milk composition of multiparous Holstein cows. It is important emphasize that increases in these parameters occurred only in one moment of sample collection, and then returned to the same values as the control group. The increase on milk fat content can be directly associated with augmentation of calcium via diet, since several studies have demonstrated the effects of calcium on lipid metabolism (Fu et al. 2011). However, this alteration should not raise concern, since the results demonstrated that it was a transitory effect. 


\section{CONCLUSION}

The use of a single dose of calcium subcutaneously maintained calcium levels above $8 \mathrm{mg} / \mathrm{dL}$, and this avoided the subclinical hypocalcemia observed in five cows in the control group. In addition, calcium application produced few alterations in milk composition at the evaluated time points, all of which can be considered positive effects. Thus, this prophylactic treatment can be considered an approach to avoid hypocalcemia in dairy cows during the post-partum period. However, it is important to emphasize that the most appropriate method to prevent hypocalcemia is the use of anionic diet in pre-partum (Albani and Da Silva 2017).

\section{ACKNOWLEDGMENTS}

We thank Coordenação de Aperfeiçoamento de Pessoal de Nível Superior (CAPES), Conselho Nacional de Desenvolvimento Científico e Tecnológico (CNPq) and Fundação de Amparo à Pesquisa e Inovação do Estado de Santa Catarina (FAPESC) for their technical and financial support.

\section{AUTHOR CONTRIBUTIONS}

Albani, Lopes and Da Silva planned the experiment and performed; Campigotto and Baldissera participated in the laboratory analysis. All authors participated in the discussion of the results and writing of the manuscript.

\section{REFERENCES}

ALBANI KD AND DA SILVA AS. 2017. Dieta com restrição de cálcio ou aniônica em vacas leiteiras no pré-parto. Arq Ciênc Vet Zool Unipar 20: 93-99.

ALBANI KD, DA SILVA AS, MACHADO G, BOTTARI NB, CAMPIGOTTO G, FRITZEN A, MORSCH VM, SCHETINGER MRC AND LOPES LS. 2017. Benefits of a Prepartum Anionic Diet on the Health of Dairy Cows in the Transition Period: Prevented Subclinical Hypocalcemia and Minimizing Oxidative Stress. Acta Sci Vet 45: 1517.
AMANLOU H, AKBARI AP, FARSUNI NE AND SILVADR. 2016. Effects of subcutaneous calcium administration at calving on mineral status, health, and production of Holstein cows. J Dairy Sci 99: 9199-9210.

BEKKELUND SI AND JOHNSEN SH. 2018. Creatine kinase is associated with reduced inflammation in a general population: The Troms study. PLoS ONE 13(5): e0198133.

BLANC CD, VAN DER LIST M, ALY SS, ROSSOW HA AND SILVA-DEL-RÍO N. 2014. Blood calcium dynamics after prophylactic treatment of subclinical hypocalcemia with oral or intravenous calcium. J Dairy Sci 97(11): 69016906.

BORSBERRY S AND DOBSON H. 1989. Periparturient diseases and their effect on reproductive performance in five dairy herds. Vet Record 124: 217-219.

CECILIANI F, LECCHI C, URH C AND SAUERWEIN H. 2018. Proteomics and metabolomics characterizing the pathophysiology of adaptive reactions to the metabolic challenges during the transition from the late pregnancy to early lactation in dairy cows. J Proteomics 178: 92-106.

CURTIS CR, ERB HN, SNIFFEN CJ, SMITH RD, POWERS PA, SMITH MC, WHITE ME, HILMAN RB AND PEARSON EJ. 1983. Association of parturient hypocalcaemia with eight periparturient disorders in Holstein cows. J Am Vet Assoc 183: 559-561.

DOMINO AR, KORZEC HC AND MCART JAA. 2017. Field trial of 2 calcium supplements on early lactation health and production in multiparous Holstein cows. J Dairy Sci 100(12): 9681-9690.

FU S, YANG L, LI P, HOFMANN O, DICKER L, HIDE W, LIN $\mathrm{X}$, WATKINS SM, IVANOV AR AND HOTAMISLIGIL GS. 2011. Aberrant lipid metabolism disrupts calcium homeostasis causing liver endoplasmic reticulum stress in obesity. Nature 473(7348): 528-531.

GOFF JP AND KOSZEWSKI NJ. 2018. Comparison of $0.46 \%$ calcium diets with and without added anions a $0.7 \%$ calcium anionic diet as a means to reduce periparturient hypocalcemia. J Dairy Sci 101: 5033-5045.

GOWDA S, DESAI PB, KULKARNI SS, HULL VV, MATH AAK AND VERNEKAR SN. 2010. Markers of renal function tests. N Am J Med Sci 2(4): 170-173.

HERNÁNDEZ-CASTELLANO LE, HERNANDEZ LL, SAUERWEIN H AND BRUCKMAIER RM. 2017. Endocrine and metabolic changes in transition dairy cows are affected by prepartum infusions of a serotonin precursor. J Dairy Sci 100(6): 5050-5057.

JAHANI-MOGHADAM M, CHASHNIDEL Y, TEIMOURIYANSARI A, MAHJOUBI E AND DIRANDEH E. 2018. Effect of oral calcium bolus administration on milk production, concentrations of minerals and metabolites in serum, early-lactation health status, and reproductive performance of Holstein dairy cows. New Zeland Vet J 66(3): 132-137. 
KIM S, SIMON E, MYERS L, HAMM LL AND JAZWINSKI SM. 2016. Programmed cell death genes are linked to elevated creatine kinase levels in unhealthy male nonagenarians. Gerontol 62(5): 519-529.

LEBLANC SJ. 2012. Interactions of metabolism, inflammation, and reproductive tract health in the post-partum period in dairy cattle. Reprod Domest Anim 47(Suppl 5): 18-30.

LEE YH, CHOI SJ, JI JD AND SONG GG. 2000. Serum creatine kinase in patients with rheumatic diseases. Clin Rheumatol 19(4): 296-300.

LENO BM, NEVES RC, LOUGE IM, CURLER MD, THOMAS MJ, OVERTON TR AND MCART JAA. 2018. Differential effects of a single dose of oral calcium based on post-partum plasma calcium concentration in Holstein cows. J Dairy Sci 101(4): 3285-3302.

MASSEY LK AND WHITING SK. 1993. Caffeine, urinary calcium, calcium metabolism and bone. J Nutr 123(9): 1611-1614.

MARTINEZ N, RISCO CA, LIMA FS, BISINOTTO RS, GRECO LF, RIBEIRO ES, MAUNSELL F, GALVÃO K AND SANTOS JE. 2012. Evaluation of peripartal calcium status, energetic profile, and neutrophil function in dairy cows at low or high risk of developing uterine disease. $\mathrm{J}$ Dairy Sci 95(12): 7158-7172.

MARTINEZ N, SINEDINO LDP, BISINOTTO RS, DAETZ R, LOPERA C, RISCO CA, GALVÃO KN, THATCHER WW AND SANTOS JEP. 2016. Effects of oral calcium supplementation on mineral and acid-base status, energy metabolites, and health of postpartum dairy cows. J Dairy Sci 99(10): 8397-8416.

MARTINEZ N, SINEDINO LDP, BISINOTTO RS, RIBEIRO ES, GOMES GC, LIMA FS, GRECO LF, RISCO CA, GALVÃO KN AND SANTOS JEP. 2014. Effect of induced subclinical hypocalcemia on physiological responses and neutrophil function in dairy cows. J Dairy Sci 97(2): 874887.

MCGRATH BA, FOX PF, MCSWEENEY PLH AND KELLY AL. 2016. Composition and properties of bovine colostrum: a review. Dairy Sci Technol 96(2): 133-158.

MCLAREN CJ, LISSEMORE KD, DUFFIELD TF, LESLIE KE, KELTON DF AND GREXTON B. 2006. The relationship between herd level disease incidence and a return over feed index in Ontario dairy herds. Can Vet J 47(8): 767-773.

OETZEL GR. 2013. Oral calcium supplementation in peripartum dairy cows. Vet Clin North Am Food Anim Pract 29(2): 447-455.

OETZEL GR AND MILLER BE. 2012. Effect of oral calcium bolus supplementation on early-lactation health and milk yield in commercial dairy herds. J Dairy Sci 95: 70517065.

REINHARDT TA, LIPPOLIS JD, MCCLUSKEY BJ, GOFF JP AND HORST RL. 2011. Prevalence of subclinical hypocalcemia in dairy herds. Vet J 188(1): 122-124.

SANTOS JEPD. 2011. Distúrbios metabólicos. In: Berchielli TT, Pires AV and Oliveira SG (Eds), Distúrbios metabólicos. Nutrição de Ruminantes. Jaboticabal. FUNEP 616(2): 439-520.

SCHLATTNER U, TOKARSKA-SCHLATTNER M AND WALLIMANN T. 2006. Mitochondrial creatine kinase in human health and disease. Biochim Biophys Acta 1762(2): 164-180.

SPEICH M, GELOT S AND DRY JF. 1998. Calcium, potassium, and creatine kinase after acute myocardial infarction: additional findings on their relations. J Am College Nutrit 7(3): 251-253.

THORNTON PK. 2010. Livestock production: recent trends, future prospects. Philos Trans R Soc Lond B Biol Sci 365(1554): 2853-2867.

VALLDECABRES A, PIRES JAA AND SILVA-DEL-RÍO N. 2018: Effect of prophylactic oral supplementation on postpartum mineral status and markers of energy balance of multiparous Jersey cows. J Dairy Sci 101(5): 4460-4472.

WALLIMANN T, WYSS M, BRDICZKA D, NICOLAYK AND EPPENBERGER HM. 1992. Intracellular compartmentation, structure and function of creatine kinase isoenzymes in tissues with high and fluctuating energy demands: The 'phosphocreatine circuit' for cellular energy homeostasis. Biochem J 281(1): 21-40. 